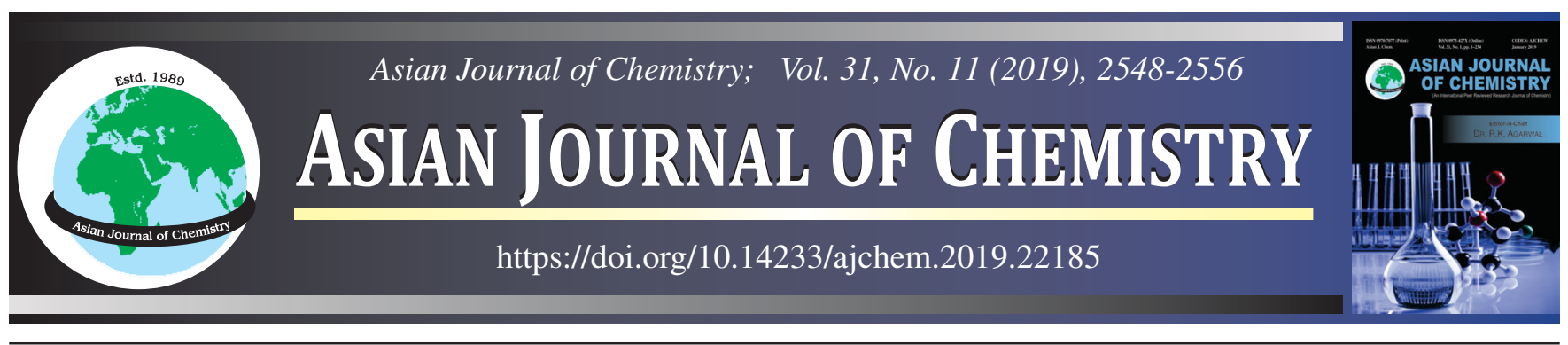

\title{
Synthesis, Molecular Docking, Cytotoxicity and Antioxidant Activity Evaluation of Isoindoline-1,3-dione Derivatives
}

Palanichamy Santhosh Kumar ${ }^{1}$, Kuruba Bharath Kumar ${ }^{2}$, Asir Obadiah ${ }^{1}$, Suluvoy Jagadish Kumar ${ }^{3}$, Raman Mohanapriya ${ }^{4}$, Arulappan Durairaj ${ }^{1}$, Subramanian Ramanathan $^{1}$ and Samuel Vasanthimumar ${ }^{1, *}$

${ }^{1}$ Department of Chemistry, Karunya Institute of Technology and Science, Coimbatore-641114, India

${ }^{2}$ School of Chemistry, Bharathidasan University, Tiruchirapalli-620024, India

${ }^{3}$ Department of Biotechnology, Karunya Institute of Technology and Science, Coimbatore-641114, India

${ }^{4}$ Department of Bioinformatics, Karunya Institute of Technology and Science, Coimbatore-641114, India

*Corresponding author: Fax: +91 422 2615615; E-mail: vasanthakumar@karunya.edu; santhoshchem2@gmail.com

\begin{abstract}
A variety of amines have been employed to functionalize isobenzofuran-1,3-dione to obtain isoindoline-1,3-dione derivatives in the base free conditions. All the synthesized compounds are screened for their bioactivity through molecular docking, cytotoxicity (against HeLa) and antioxidant activity. ABTS and DPPH are employed to assess the antioxidant activity. Among the synthesized isoindoline-1,3-dione derivatives (3a-k), compound $\mathbf{3 e}$ has showed the best antioxidant activity and also exhibited better binding energy when docked with caspase-3 protein. Cytotoxicity of the synthesized compounds was studied against cervical cancer cell line (HeLa) and compound $\mathbf{3 e}$ has displayed better activity than other isoindoline derivatives.
\end{abstract}

Keywords: Isobenzofuran-1,3-dione, Isoindoline-1,3-dione, Molecular docking, Cytotoxicity, HeLa cell lines, Antioxidant activity.

L

\section{INTRODUCTION}

Malignant growth is a gathering of ailments including strange cell development with the possibility to attack or spread to different parts of the body. It is a critical and infamous disease in the present world. A dangerous development is a risky disease and but treatable if it is diagnosed at the beginning time. Now a days, various treatment procedures are available for cancer, some of them are surgery [1], radiation therapy [2], chemotherapy, immunotherapy, targeted therapy [3], hormone therapy and stem cell transplant. In light of the impediment of medical procedure and radiotherapy in affecting a solution for disease, chemotherapy has turned out to be progressively essential. Chemotherapy is the use of any drug to treat any disorder. In any case, to by far most, the word chemotherapy infers drugs used for ailment treatment [4]. Medicinal technique and radiation treatment oust, butcher or damage danger cells in a particular part, anyway chemo can work all through the whole body. This suggests chemo can slaughter harmful development cells that have spread (metastasized) to parts of the body a long way from the primary (fundamental) tumor. Thus, recognizing evidence of a novel solid, specific, and less destructive anticancer expert remains a champion among the most crushing challenges in primary medical care [5].

Antioxidant and molecular docking studies are basic procedures to discover new anticancer experts. Disease avoidance specialists are iotas, trademark or produced, outfitted for working together with free radicals and stopping their chain reactions before crucial essential particles are damaged [6]. The mixes having antioxidant and free radical rummaging properties are considered for use for the balancing activity or treatment of human diseases [7]. A couple of sicknesses, for instance, illness like Alzheimer and Parkinson can be progressed by free radicals [8]. Antioxidants go about as an important assurance against radical mediated noxious quality by getting the free radicals [9]. Molecular docking is a charming structure to appreciate quiet bimolecular correspondences for the rational medicine plan and discovery [10]. Molecular docking is the association of something like two particles to give a consistent adduct. The guideline focus of molecular docking is to achieve ligand-

This is an open access journal, and articles are distributed under the terms of the Attribution 4.0 International (CC BY 4.0) License. This license lets others distribute, remix, tweak, and build upon your work, even commercially, as long as they credit the author for the original creation. You must give appropriate credit, provide a link to the license, and indicate if changes were made. 
receptor complex with upgraded adjustment and with the objective of having less confining free energy [10]. Various proteins and impetuses are used as targets or receptors in atomic docking.

The discovery and evaluation of organic compounds with a specific pharmacological activity is a necessary task in the drug development process. Among the large variety of organic compounds, heterocyclic compounds have been extensively studied due to their important pharmacological properties and applications [11]. Heterocyclic compounds display an array of interesting properties [12] and exploration of their potency is always worth investigating. Among divergent varieties of heterocyclic compounds, N-heterocyclic compounds [13] occupy centre stage due to their proven bioactivity. Isoindoline-1,3diones [14] are a group of typical annulated N-heterocyclic compounds which have attracted much attention, in the recent past. They have been widely studied for their anticancer [15], antimicrobial [16], antioxidant [17], anti-inflammatory [18], antipsychotic [19], anticonvulsive [20] and antihypertensive [21] properties. Reports are also available on isoindoline-1,3diones as enzyme inhibitor towards RSK2 [22], cytotoxic activity [23] towards T47D cancer cell line and as a possible 15-lipoxygenase-1-inhibitor [24]. Owing to their interesting properties, isoindoline-1,3-diones are considered as the promising chemical entities whose potential is worth investigating.

All the synthesized isoindoline-1,3-dione derivatives were thoroughly analyzed and their structures are confirmed using FTIR, NMR $\left({ }^{1} \mathrm{H}\right.$ and $\left.{ }^{13} \mathrm{C}\right)$ and mass spectroscopy techniques. For all the synthesized compounds, molecular docking, antioxidant and cytotoxicity studies were carried out to evaluate their bioactivity.

\section{EXPERIMENTAL}

All the chemicals and reagents employed for the synthesis of isoindoline-1,3-dione derivatives (3a-k) were purchased from Sigma-Aldrich. All the reagents and solvents were obtained from Aldrich and used without further purification. Doxorubicin was purchased from Pfizer Pharma, India. ABTS was purchased from Nice chemicals Ltd., India. ${ }^{1} \mathrm{H}$ and ${ }^{13} \mathrm{C}$ NMR spectra were recorded on a Bruker FT-500 using tetramethylsilane (TMS) as an internal standard. The IR spectra were recorded on a Shimadzu FTIR spectrophotometer using $\mathrm{KBr}$ (4000-400 $\mathrm{cm}^{-1}$ ). The compounds were purified by column chromatography using silica gel (100-200 mesh) and petroleum ether:ethyl acetate. TLC was performed using silica gel 60 $\mathrm{F}_{254}$ pre-coated on aluminum sheets, obtained from Merck. Visualization of spots on TLC plate was done with UV light $(254 \mathrm{~nm})$. in vitro Cytotoxicity of all the compounds was studied by cell viability assay method. Molecular docking studies of all the synthesized compounds were studied by Hex 8.0.0 docking software.

Completion of all the reactions were checked by thin layer chromatography (TLC silica gel $0.25 \mathrm{~mm}, 60 \mathrm{G} \mathrm{F}_{254}$ and the eluting solvents were ethyl acetate:hexane). All the compounds were characterized by FT-IR spectrometer (IR Prestige-21, Shimadzu, Japan) using $\mathrm{KBr}$ pellets, ${ }^{1} \mathrm{H}$ NMR spectroscopy in DMSO (500 MHz, Bruker) and ${ }^{13} \mathrm{C}$ NMR spectroscopy in
DMSO (125 MHz, Bruker) using tetramethylsilane (TMS) as an internal standard. Mass spectra were measured by the Electron Impact (EI) method (Jeol GC-Mate 2). Absorbance of antioxidants was measured by spectrophotometer (ELICO SL 207 mini spec). in vitro Cytotoxicity of all the compounds was studied by cell viability assay method. Cytotoxicity assay evaluated using the cell culture facilities, which includes a laminar flow hood and a $37^{\circ} \mathrm{CCO}_{2}$ incubator. Molecular docking studies were performed using Hex 8.0.0 docking software.

Synthesis of isoindoline-1,3-dione derivatives (3a-k): To a solution of isobenzofuran-1,3-dione $(1.48 \mathrm{~g}, 10 \mathrm{mmol})$ in methanol $(4 \mathrm{~mL} / 1 \mathrm{mmol})$ at room temperature was added aliphatic or aromatic amine $(10 \mathrm{mmol})$ and the reaction mixture was refluxed at $65^{\circ} \mathrm{C}$ for $4 \mathrm{~h}$. After completion of the reaction as indicated by the TLC, the reaction was cooled to room temperature and purified by column chromatography using petroleum ether:ethyl acetate $(7: 3)$.

2-(4-(4-Aminobenzyl)phenyl)isoindoline-1,3-dione (3a): White solid; m.p.: > $300{ }^{\circ} \mathrm{C}$, yield: $1.968 \mathrm{~g}, 60 \%$; IR ( $\mathrm{KBr}$, $\left.v_{\max }, \mathrm{cm}^{-1}\right): 717(\mathrm{C}-\mathrm{H}), 1373(\mathrm{C}-\mathrm{N}), 1512(\mathrm{C}=\mathrm{C}), 1720(\mathrm{C}=\mathrm{O})$; ${ }^{1} \mathrm{H}$ NMR (500 MHz, DMSO- $d_{6}$ ): 7.91-8.10 (2H, Ar-phthalic), 7.6-7.7 (2H, Ar-phthalic), 6.3-7.8 (8H, Ar-benzene), $4.00(2 \mathrm{H}$, $\left.-\mathrm{NH}_{2}\right), 3.33\left(2 \mathrm{H}, \mathrm{CH}_{2}\right) ;{ }^{13} \mathrm{C}$ NMR (125 MHz, DMSO- $\left.d_{6}\right): 127$, 131 (6C, Ar-phthalic), 137, 130, 125 (3C, CN, C- $\mathrm{CH}_{2}, \mathrm{CH}_{2} \mathrm{C}$ ), 128.8, 128.4, 128.2, 124 (8C, Ar-benzene), 148 (1C, $\mathrm{CNH}_{2}$ ), 54.1 (1C, $\left.\mathrm{CH}_{2}\right), 167.5(3 \mathrm{C}, \mathrm{C}=\mathrm{O})$; MS (EI): $\mathrm{m} / z[\mathrm{M}+\mathrm{H}]^{+}$: Calcd. for $\mathrm{C}_{21} \mathrm{H}_{15} \mathrm{~N}_{2} \mathrm{O}_{2}$ : 328.3639; found:328.3601.

4-(1,3-dioxoisoindolin-2-yl) benzoic acid (3b): White solid; m.p.: $290{ }^{\circ} \mathrm{C}$, yield: $1.78 \mathrm{~g}, 67 \%$; IR $\left(\mathrm{KBr}, \nu_{\max }, \mathrm{cm}^{-1}\right)$ : $713(\mathrm{C}-\mathrm{H}), 1300(\mathrm{C}-\mathrm{N}), 1378(\mathrm{C}=\mathrm{C}), 1714(\mathrm{C}=\mathrm{O}) ;{ }^{1} \mathrm{H}$ NMR (500 MHz, DMSO- $d_{6}$ ): 7.61-7.62 (2H, Ar-phthalic), 7.91-8.00 (2H, Ar-phthalic), 7.92-7.93 (2H, Ar-benzene), 8.00-8.10 (2H, Ar-benzene), $10.8(1 \mathrm{H}, \mathrm{OH}) ;{ }^{13} \mathrm{C}$ NMR $(125 \mathrm{MHz}$, DMSO$\left.d_{6}\right): 127,131,130$ (6C, Ar-phthalic), 146 (1C, CN), 121, 124, 135 (5C, Ar-benzene), 171, 167.12 (3C, C=O); MS (EI): $\mathrm{m} / \mathrm{z}$ $[\mathrm{M}+\mathrm{H}]^{+}$: Calcd. for $\mathrm{C}_{15} \mathrm{H}_{9} \mathrm{NO}_{4}: 267.0531$; found: 267.0012 .

2-(2-Aminoethyl)isoindoline-1,3-dione (3c): White solid; m.p.: $190{ }^{\circ} \mathrm{C}$, yield: $1.31 \mathrm{~g}, 69 \%$; IR $\left(\mathrm{KBr}, \mathrm{v}_{\max }, \mathrm{cm}^{-1}\right): 719$ (C-H), 1316 (C-N), 1397 (C=C), 1709 (C=O), $3064(\mathrm{C}-\mathrm{H})$; ${ }^{1} \mathrm{H}$ NMR (500 MHz, DMSO- $\left.d_{6}\right): 1.71\left(2 \mathrm{H}, \mathrm{NH}_{2}\right), 3.35,3.85$ (4H, $\mathrm{CH}_{2} \mathrm{CH}_{2}$ ), 7.8-8.2 (4H, Ar-phthalic); ${ }^{13} \mathrm{C}$ NMR $(125 \mathrm{MHz}$, DMSO- $\left.d_{6}\right): 36.7,54.1\left(2 \mathrm{C}, \mathrm{CH}_{2} \mathrm{CH}_{2}\right), 123.5,131.8,134.9(6 \mathrm{C}$, Ar-phthalic), 168.2 (2C, C=O); MS (EI): $m / z[\mathrm{M}+\mathrm{H}]^{+}$: Calcd. for $\mathrm{C}_{10} \mathrm{H}_{10} \mathrm{~N}_{2} \mathrm{O}_{2}$ : 190.1986; found: 190.4626 .

2-(2-Methyl-5-nitrophenyl)isoindoline-1,3-dione (3d): White solid; m.p.: $213{ }^{\circ} \mathrm{C}$, yield: $1.80 \mathrm{~g}, 64 \%$; IR $\left(\mathrm{KBr}, v_{\max }\right.$, $\left.\mathrm{cm}^{-1}\right): 788(\mathrm{C}-\mathrm{H}), 1345(\mathrm{C}-\mathrm{N}), 1544(\mathrm{C}=\mathrm{C}), 1710(\mathrm{C}=\mathrm{O}) ;{ }^{1} \mathrm{H}$ NMR (500 MHz, DMSO- $\left.d_{6}\right)$ : 7.9-8.0 (2H, Ar-phthalic), 7.67.7 (2H, Ar-phthalic), 7.52-7.79 ( 2H, Ar-benzene), $8.4(1 \mathrm{H}$, Ar-benzene), $2.35\left(3 \mathrm{H}, \mathrm{CH}_{3}\right) ;{ }^{13} \mathrm{C}$ NMR (125 MHz, DMSO$\left.d_{6}\right): 129,131,132$ (6C, Ar-phthalic), 141 (1C, C-NO $\left.{ }_{2}\right), 137$ (1C, $\mathrm{CN}), 18.5\left(1 \mathrm{C}, \mathrm{CH}_{3}\right), 128,130.0,130.1$ (3C, Ar-benzene), $139\left(1 \mathrm{C}, \mathrm{CCH}_{3}\right), 167(2 \mathrm{C}, \mathrm{C}=\mathrm{O})$; $\mathrm{MS}(\mathrm{EI}): \mathrm{m} / z[\mathrm{M}+\mathrm{H}]^{+}$: Calcd. for $\mathrm{C}_{15} \mathrm{H}_{10} \mathrm{~N}_{2} \mathrm{O}_{4}$ : 282.2509; found: 282.2504.

2-(4-(4-Aminophenylsulfonyl) phenyl)isoindoline-1,3dione (3e): White solid; m.p.: $>300{ }^{\circ} \mathrm{C}$, yield: $1.82 \mathrm{~g}, 64 \%$; IR (KBr, $\left.v_{\max }, \mathrm{cm}^{-1}\right): 744(\mathrm{C}-\mathrm{H}), 1376(\mathrm{C}-\mathrm{N}), 1592(\mathrm{C}=\mathrm{C})$, $1709(\mathrm{C}=\mathrm{O}) ;{ }^{1} \mathrm{H}$ NMR $\left(500 \mathrm{MHz}, \mathrm{DMSO}-d_{6}\right)$ : 8.0-8.2 $(2 \mathrm{H}$, 
Ar-phthalic), 7.6-7.8 (2H, Ar-phthalic), 6.2-6.8 (2H, Arbenzene), 7.6-7.9 (6H, Ar-benzene), $3.36\left(2 \mathrm{H}, \mathrm{NH}_{2}\right) ;{ }^{13} \mathrm{C}$ NMR (125 MHz, DMSO- $\left.d_{6}\right): 127,131$ (6C, Ar-phthalic), 142, 140, 130 (3C, CN, CS, SC), 128.7, 128.3, 128.2, 125 (8C, Ar-benzene), 154 (1C, $\left.\mathrm{CNH}_{2}\right), 166$ (2C, $\left.\mathrm{C}=\mathrm{O}\right)$; MS (EI): $m / z$ [M+H] $]^{+}$Calcd. for $\mathrm{C}_{20} \mathrm{H}_{14} \mathrm{~N}_{2} \mathrm{O}_{4} \mathrm{~S}$ : 378.4011 ; found: 378.4014 .

2-Benzylisoindoline-1,3-dione (3f): White solid; m.p.: $115^{\circ} \mathrm{C}$, yield: $1.50 \mathrm{~g}, 63 \%$; IR $\left(\mathrm{KBr}, v_{\max }, \mathrm{cm}^{-1}\right): 717(\mathrm{C}-\mathrm{H})$, $1329(\mathrm{C}-\mathrm{N}), 1389(\mathrm{C}=\mathrm{C}), 1712(\mathrm{C}=\mathrm{O}), 3059(\mathrm{C}-\mathrm{H}) ;{ }^{1} \mathrm{H}$ NMR $\left(500 \mathrm{MHz}, \mathrm{DMSO}-d_{6}\right): 4.77\left(2 \mathrm{H}, \mathrm{CH}_{2}\right), 7.2-7.3(2 \mathrm{H}, \mathrm{Ar}-$ benzene), 7.3-7.4 (3H, Ar-benzene), 7.84-7.85 (2H, Arphthalic), 7.86-7.90 (2H, Ar-phthalic); ${ }^{13} \mathrm{C}$ NMR (125 MHz, DMSO- $\left.d_{6}\right): 41.3\left(1 \mathrm{C}, \mathrm{H}_{2} \mathrm{C}-\mathrm{N}\right), 123.6,127.8,129.0,137.1$ (6C, Ar-benzene), 127.8, 132.0, 135.0 (6C, Ar-phthalic), 168.1 (2C, $\mathrm{C}=\mathrm{O}$ ); $\mathrm{MS}$ (EI): $\mathrm{MS}(\mathrm{EI}): \mathrm{m} / z[\mathrm{M}+\mathrm{H}]^{+}$: Calcd. for $\mathrm{C}_{15} \mathrm{H}_{11} \mathrm{NO}_{2}$ : 237.0789; found: 237.0709.

2-(Pyridin-2-yl)isoindoline-1,3-dione (3g): White solid; m.p.: $223{ }^{\circ} \mathrm{C}$, yield: $1.40 \mathrm{~g}, 62 \%$; IR $\left(\mathrm{KBr}, \mathrm{v}_{\max }, \mathrm{cm}^{-1}\right): 781$ $(\mathrm{C}-\mathrm{H}), 1377(\mathrm{C}-\mathrm{N}), 1454(\mathrm{C}=\mathrm{C}), 1711(\mathrm{C}=\mathrm{O}), 3045(\mathrm{C}-\mathrm{H})$; ${ }^{1} \mathrm{H}$ NMR (500 MHz, DMSO- $\left.d_{6}\right)$ : 7.53-7.56 (1H, Ar-benzene), 8.1 (1H, Ar-benzene), 6.5-6.6 (1H, Ar-benzene), 6.6-6.7 $(1 \mathrm{H}$, Ar-benzene), 7.9-7.93 (2H, Ar-phthalic), 7.96-8.03 (2H, Arphthalic); ${ }^{13} \mathrm{C}$ NMR (125 MHz, DMSO- $d_{6}$ ): 123.5, 124.1, 139.1 (3C, Ar-benzene), 124.5, 131.8, 135.8 (6C, Ar-phthalic), 146.4, 149.8 (2C, C-N), 166.9 (2C, C=O); MS (EI): $m / z,[\mathrm{M}+\mathrm{H}]^{+}$: Calcd. for $\mathrm{C}_{13} \mathrm{H}_{8} \mathrm{~N}_{2} \mathrm{O}_{2}$ : 224.0585; found: 224.0510 .

2-Phenylisoindoline-1,3-dione (3h): White solid; m.p.: $205{ }^{\circ} \mathrm{C}$, yield: $1.60 \mathrm{~g}, 71 \%$; IR $\left(\mathrm{KBr}, v_{\max }, \mathrm{cm}^{-1}\right)$ : $759(\mathrm{C}-\mathrm{H})$, $1381(\mathrm{C}-\mathrm{N}), 1495(\mathrm{C}=\mathrm{C}), 1710(\mathrm{C}=\mathrm{O}), 3063(\mathrm{C}-\mathrm{H}) ;{ }^{1} \mathrm{H}$ NMR (500 MHz, DMSO- $d_{6}$ ): 7.43-7.46 (3H, Ar-benzene), 7.52-7.55 (2H, Ar-phthalic), 7.9-7.93 (2H, Ar-benzene), 7.96-7.98 (2H, Ar-phthalic); ${ }^{13} \mathrm{C}$ NMR (125 MHz, DMSO- $\left.d_{6}\right): 121.4,123.8$, 129.3 (5C, Ar-benzene), 127.8, 132.0, 132.3 (6C, Ar-phthalic), 133 (1C, C-N), $167.4(2 \mathrm{C}, \mathrm{C}=\mathrm{O})$; MS (EI): $\mathrm{m} / z[\mathrm{M}+\mathrm{H}]^{+}$: Calcd. for $\mathrm{C}_{14} \mathrm{H}_{9} \mathrm{NO}_{2}$ : 223.0683; found: 223.0605 .

2-Ethylisoindoline-1,3-dione (3i): White solid; m.p.: 75 ${ }^{\circ} \mathrm{C}$, yield: $1.05 \mathrm{~g}, 60 \%$; IR $\left(\mathrm{KBr}, v_{\max }, \mathrm{cm}^{-1}\right): 718(\mathrm{C}-\mathrm{H}), 1394$ $(\mathrm{C}-\mathrm{N}), 1450(\mathrm{C}=\mathrm{C}), 1715(\mathrm{C}=\mathrm{O}), 2942(\mathrm{C}-\mathrm{H}) ;{ }^{1} \mathrm{H}$ NMR (500 MHz, DMSO- $\left.d_{6}\right)$ : $1.15-1.18\left(3 \mathrm{H}, \mathrm{CH}_{3}\right), 3.58-3.62\left(2 \mathrm{H}, \mathrm{CH}_{2}\right)$, 8.0-8.2 (2H, Ar-phthalic), 7.81-7.86 (2H, Ar-phthalic); ${ }^{13} \mathrm{C}$
NMR (125 MHz, DMSO-d 6$)$ : $14.0\left(\mathrm{CH}_{3}\right), 32.8\left(\mathrm{CH}_{2}\right), 123.3$, 132.1, 134.7 (6C, Ar-phthalic), 168.1 (2C, C=O); MS (EI): $\mathrm{m} / \mathrm{z}$ $[\mathrm{M}+\mathrm{H}]^{+}$: Calcd. for $\mathrm{C}_{10} \mathrm{H}_{9} \mathrm{NO}_{2}$ : 175.1839; found: 175.2104 .

3-Amino-5-(1,3-dioxoisoindolin-2-yl)benzoic acid (3j): White solid; m.p.: $>300{ }^{\circ} \mathrm{C}$, yield: $1.85 \mathrm{~g}, 65 \%$; IR ( $\mathrm{KBr}, v_{\max }$, $\left.\mathrm{cm}^{-1}\right): 710(\mathrm{C}-\mathrm{H}), 1301(\mathrm{C}-\mathrm{N}), 1373(\mathrm{C}=\mathrm{C}), 1735(\mathrm{C}=\mathrm{O}), 3064$ (C-H); NMR (500 MHz, DMSO- $\left.d_{6}\right)$ : 7.8-8.0 (2H, Ar-phthalic), 7.85-7.96 (2H, Ar-phthalic), 8.25, 8.15, 7.71 (3H, Ar-benzene), $3.85\left(2 \mathrm{H}, \mathrm{NH}_{2}\right), 10.3(1 \mathrm{H}, \mathrm{COOH}) ;{ }^{13} \mathrm{C} \mathrm{NMR}(125 \mathrm{MHz}$, DMSO- $\left.d_{6}\right): 124.1,131,135$ (6C, Ar-phthalic), 139, 124.6 (2C, $\mathrm{CN}, \mathrm{C}-\mathrm{COOH}$ ), 110, 110.3, 113 (3C, Ar-benzene), 166, 169 (3C, $\mathrm{C}=\mathrm{O}), 146\left(1 \mathrm{C}, \mathrm{C}-\mathrm{NH}_{2}\right)$; MS (EI): $m / z,[\mathrm{M}+\mathrm{H}]^{+}$: Calcd. for $\mathrm{C}_{15} \mathrm{H}_{10} \mathrm{~N}_{2} \mathrm{O}_{4}$ : 282.2509; found: 282.2504 .

2-(4-Chlorophenyl)isoindoline-1,3-dione (3k): White solid; m.p.: $201{ }^{\circ} \mathrm{C}$, yield: $1.80 \mathrm{~g}, 70 \%$; IR $\left(\mathrm{KBr}, v_{\max }, \mathrm{cm}^{-1}\right)$ : $708(\mathrm{C}-\mathrm{H}), 1390(\mathrm{C}-\mathrm{N}), 1491(\mathrm{C}=\mathrm{C}), 1714(\mathrm{C}=\mathrm{O}), 3067(\mathrm{C}-\mathrm{H})$; ${ }^{1} \mathrm{H}$ NMR (500 MHz, DMSO- $d_{6}$ ): 7.90-7.95 (2H, Ar-benzene), 7.50-7.55 (2H, Ar-benzene), 7.4-7.5 (2H, Ar-phthalic), 7.908.03 (2H, Ar-phthalic); ${ }^{13} \mathrm{C}$ NMR (125 MHz, DMSO- $d_{6}$ ): 123.5 , 128.4 (4C, Ar-benzene), 127.8, 132.0, 132.3 (6C, Ar-phthalic), 129.5 (1C, C-Cl), 135.1 (1C, C-N), 167.5 (2C, C=O); MS (EI): $m / z[\mathrm{M}+\mathrm{H}]^{+}$: Calcd. for $\mathrm{C}_{14} \mathrm{H}_{8} \mathrm{NO}_{2} \mathrm{Cl}$ : 257.0243; found: 257.0214.

Molecular docking studies: Three dimensional structure of Caspase-3 was found as a complex with Y195A showed in Fig. 1. This was retrieved from the PDB (Protein Data Bank). Caspase-3 [25] receptor was docked with different ligands (3a-k, standard) using Hex 8.0.0 docking software [26,27]. It is an interactive Molecular Graphics Program that calculates and displays possible docking modes of pairs of protein and DNA molecules and also analyzes protein-ligand docking. Hex docking was carried out by setting appropriate parameters such as twist range-360, receptor range-180, FFT mode-5D, ligand range180 , grid dimension- 0.6 and distance range- 40 and correlation type of shape complementarily and electrostatics. The binding energy of the compounds 3a-k and the caspase inhibitor III (standard) has been tabulated.

in vitro Antioxidant activity: The compounds 3a-k were tested for in vitro antioxidant activity by DPPH and ABTS methods.

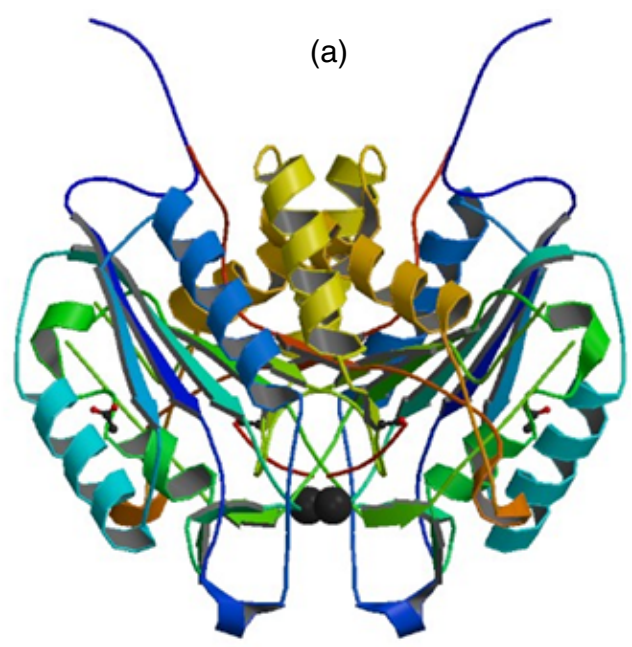

(b)<smiles>CC(=O)N[C@@H](CC(=O)O)C(=O)N[C@@H](CCC(=O)O)C(=O)N[C@H](C(=O)N[C@@H](CC(=O)O)C(=O)CCl)C(C)C</smiles>

Fig. 1. (a) HeLa cell line protein Caspase-3 complex with Y195A retrieved from PDB (PDB ID: 4QTX) (b) The 2D structure of Caspase Inhibitor III retrieved from PDB 
DPPH radical scavenging activity: DPPH is a stable free radical with a red colour (absorption at $517 \mathrm{~nm}$ ). When the free radicals are scavenged, the DPPH will generate a yellow colour. A solution of DPPH $(0.1 \mathrm{~mL}, 0.000985 \mathrm{~g})$ in methanol $(25 \mathrm{~mL})$ was prepared. Then this solution $(1.0 \mathrm{~mL})$ was added to the sample solution (1:1) in methanol at different concentrations (0.5-5.0 mM). After $30 \mathrm{~min}$, the absorbance was measured at $517 \mathrm{~nm}$ [28]. A blank was prepared without adding the sample solution. In this study, it is understood that lower the absorbance of the reaction mixture, higher is the free radical scavenging activity. The inhibitory percentage of DPPH was calculated according to the following equation:

$$
\text { Inhibition }(\%)=\frac{\mathrm{Abs}_{\text {control }}-\mathrm{Abs}_{\text {sample }}}{\mathrm{Abs}_{\text {control }}} \times 100
$$

where, $\mathrm{Abs}_{\text {control }}$ is the absorbance of DPPH solution and $\mathrm{Abs}_{\text {sample }}$ is the absorbance of DPPH solution + sample (test samples). $\mathrm{IC}_{50}$ values were calculated from the calibration curve.

ABTS radical scavenging activity: A solution of ABTS $(7 \mathrm{mM}, 0.0384 \mathrm{~g})$ in distilled water $(10 \mathrm{~mL})$ was mixed with aqueous potassium persulphate $(2.45 \mathrm{mM}, 0.0066 \mathrm{~g})$ [29]. The mixture was kept in dark at room temperature and left overnight. Further, the mixture was diluted with methanol $(20 \mathrm{~mL})$ to give the absorbance at $734 \mathrm{~nm}$. Different concentrations of sample $(0.5-5.0 \mathrm{mM})$ was prepared using methanol and mixed with ABTS mixture in the ratio of 9:1. This was kept in the dark for $1 \mathrm{~h}$ and then the absorbance was noted at $734 \mathrm{~nm}$ [30]. The inhibitory percentage of ABTS was calculated as follows:

$$
\text { Inhibition }(\%)=\frac{\mathrm{Abs}_{\text {control }}-\mathrm{Abs}_{\text {sample }}}{\mathrm{Abs}_{\text {control }}} \times 100
$$

where, $\mathrm{Abs}_{\text {control }}$ is the absorbance of ABTS mixture and $\mathrm{Abs}_{\text {sample }}$ is the absorbance of ABTS mixture + sample (test samples). Lower the absorbance of the reaction mixture, the higher the free radical scavenging activity. The result of radical scavenging also expressed in terms of half-inhibition concentration $\left(\mathrm{IC}_{50}\right)$, which denotes the concentration required to scavenge $50 \%$ of ABTS radicals.

in vitro Cytotoxicity activity: The in vitro cytotoxic activities of the synthesized compounds are evaluated by cell viability assay method (MTT assay) against a human cervical cancer cell line (HeLa). MTT is a quantitative colorimetric method for determining cell proliferation after treatment with the tested compounds. MTT, a tetrazolium compound (3-[4,5-dimethylthiazol-2-yl]-2,5-diphenyltetrazolium bromide) will reduce metabolically active cells to insoluble purple formazan dye crystals, which indicates the inhibition of cells. It is widely used to estimate the cytotoxic action of chemicals on different types of cells [31,32]. In this method, HeLa (cervical cancer cell line) were seeded (80 to 90 confluency) in flat-bottomed 96-well tissue culture plates and incubated for $24 \mathrm{~h}$. After incubation, the isoindoline-1,3-dione derivatives (3a-k) were added to each at $6,12,25,55$ and $85 \mu \mathrm{L}$ concentrations, respectively. The standard drug (doxorubicin) was also added as control. The test sample and standard were incubated in the 96-well tissue culture plates for $24 \mathrm{~h}$ and the MTT was added followed by $3 \mathrm{~h}$ incubation. Detergent is then added to the wells solubilizing the crystals and the optical density values were noted spectro- photometrically at $570 \mathrm{~nm}$ [33]. The data was analyzed by plotting concentration of test samples versus absorbance, allowing the quantitation changes in cell proliferation. The rate of tetrazolium reduction is proportional to the rate of cell proliferation [34].

\section{RESULTS AND DISCUSSION}

Isoindoline-1,3-dione derivatives were synthesized from isobenzofuran-1,3-dione in the absence of a base or a Lewis acid. For the preparation of desired isoindoline-1,3-dione derivatives a variety of aliphatic and aromatic amines have been employed and the reaction was carried out by refluxing in methanol for $4 \mathrm{~h}$ (Scheme-I). A tedious workup procedure is required to remove the base from the reaction mixture. In order to circumvent the workup procedure, a base-free method was adopted for the synthesis of isoindoline-1,3-dione derivatives. Reaction optimization was carried out to select the suitable solvent and the results are tabulated in Table-1. It is clear that the reactions carried out in halogenated solvents resulted in poor yields, whereas methanol and ethanol are found to be the preferred choice of solvents for this chemical transformation. Further, methanol was selected over ethanol due to its low boiling point, which makes it easier to evaporate it after the completion of reaction. After reaction optimization, isobenzofuran-1,3-dione was subjected to reaction with a variety of amines and the results are shown in Table-2. It was observed that even under the slightly altered reaction conditions, the desired products are formed smoothly and in good yields. Aliphatic amines, substituted aromatic as well as heterocyclic amines functionalized isobenzofuran-1,3-dione to give isoindoline1,3-dione derivatives. All the synthesized compounds were thoroughly analyzed and their structures are confirmed using FTIR, NMR ( ${ }^{1} \mathrm{H}$ and ${ }^{13} \mathrm{C}$ ), and mass spectroscopy techniques.

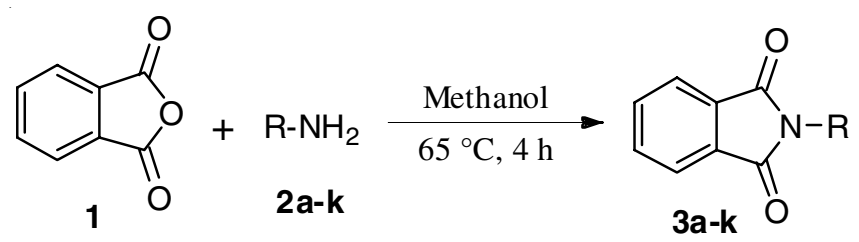

Scheme-I: Synthesis of isoindoline-1,3-dione derivatives

\begin{tabular}{clc}
\multicolumn{3}{c}{ TABLE-1 } \\
& \multicolumn{1}{c}{ SOLVENT SCREENING } \\
\hline Entry & \multicolumn{1}{c}{ Solvent } & \\
\hline 1 & Dichloromethane & Yield $^{\mathrm{b}}(\%)$ \\
\hline 2 & Chloroform & 20 \\
3 & Tetrahydrofuran & 18 \\
4 & Acetone & 37 \\
5 & Methanol & 65 \\
6 & Ethanol & 71 \\
7 & Isopropyl alcohol & 68 \\
8 & Toluene & 57 \\
\hline
\end{tabular}

${ }^{a}$ Reaction conditions: Isobenzofuran-1,3-dione (10 mmol), amine (10 mmol) in solvent $(4 \mathrm{~mL} / 1 \mathrm{mmol})$, refluxed for $4 \mathrm{~h}$ at $65{ }^{\circ} \mathrm{C}$; ${ }^{\text {b Yield }}$ corresponding to the isolated product either by column chromatography or recrystallization.

Molecular docking studies: Bioinformatics is ascending as a basic gadget in the field of pharmaceutical and prescription improvement with the colossal unconstrained formation of API. Caspase (cysteine aspartic protease) is a family of protease enzymes 


\section{SYNTHESIS OF ISOINDOLINE-1,3-DIONEDERIVATIVES}

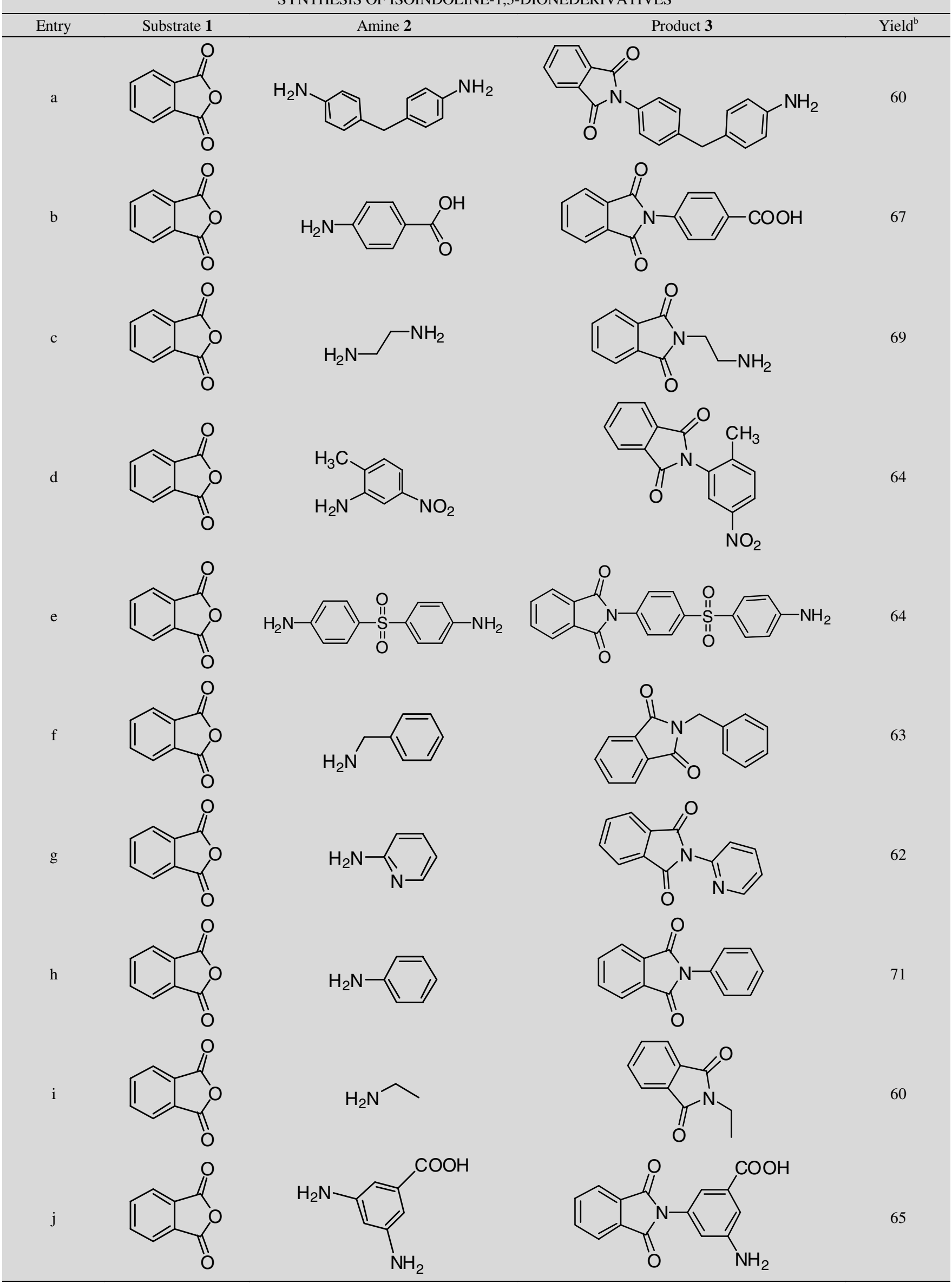




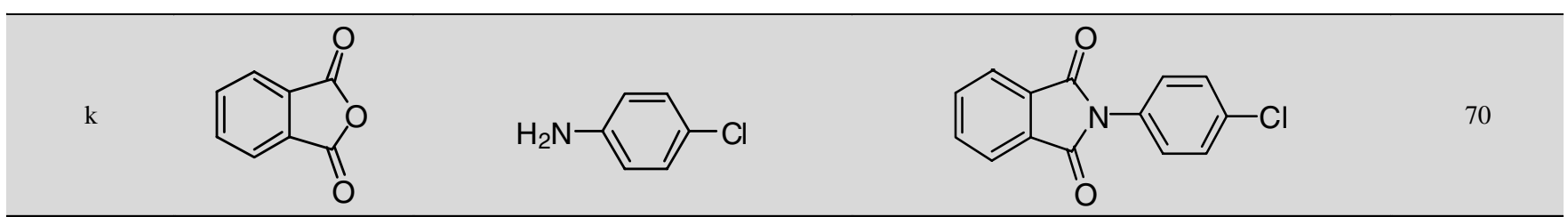

${ }^{\text {a } R e a c t i o n ~ c o n d i t i o n s: ~ I s o b e n z o f u r a n-1,3-d i o n e ~}(10 \mathrm{mmol})$, amine $(10 \mathrm{mmol})$, methanol $(40 \mathrm{~mL})$, refluxed at $65{ }^{\circ} \mathrm{C}$ for $4 \mathrm{~h}$; ${ }^{\text {b } Y i e l d ~ c o r r e s p o n d i n g ~ t o ~}$ the isolated product through column chormatography or recrystallization.

playing essential roles in programmed cell death (including apoptosis, pyroptosis and necrooptosis) and inflammation. Caspase3 has been found to be necessary for normal brain development as well as its typical role in apoptosis, where it is responsible for chromatin condensation and DNA fragmentation [35].

All the synthesized compounds $\mathbf{3 a}-\mathbf{k}$ were defined as ligands and the molecular docking was performed using caspase- 3 as a receptor in Hex 8.0.0 software. After molecular docking, calculated binding free energies (Kcal/mol) were observed for each ligand (Table-3). The comparison of binding free energies shows that compound $\mathbf{3 e}$ has the best interaction with caspase3 (Fig. 2). Higher the negative $\mathrm{E}_{\text {total }}$ value, stronger is the interaction between ligand and receptor, which leads to activation of receptors. The compound $\mathbf{3 g}$ displayed hydrogen bond interactions with the active site of the protein as showed in Fig. 3. Among eleven isoindoline-1,3-dione derivatives, compounds

\begin{tabular}{ccccc}
\hline \multicolumn{5}{c}{ TABLE-3 } \\
DOCKING RESULTS OF CASPASE-3 RECEPTOR WITH \\
ISOINDOLINE-1,3-DIONE DERIVATIVES AND STANDARD \\
\hline Compd. & $\begin{array}{c}\text { Hela cell } \\
\text { line protein } \\
\text { (Receptor) }\end{array}$ & $\begin{array}{c}\text { Docking } \\
\text { score } \text { E }_{\text {total }} \\
\text { value } \\
(\mathrm{KJ} / \mathrm{mol})\end{array}$ & $\begin{array}{c}\mathrm{E}_{\text {shape }} \\
\text { (energy } \\
\text { content of } \\
\text { the protein) }\end{array}$ & $\begin{array}{c}\mathrm{E}_{\text {force }} \\
\text { (binding } \\
\text { energy of } \\
\text { ligand) }\end{array}$ \\
\hline $\mathbf{3 a}$ & Casepase-3 & -249.3 & -249.3 & 0.0 \\
$\mathbf{3 b}$ & Casepase-3 & -212.6 & -212.6 & 0.0 \\
$\mathbf{3 c}$ & Casepase-3 & -193.7 & -193.7 & 0.0 \\
$\mathbf{3 d}$ & Casepase-3 & -234.7 & -234.7 & 0.0 \\
$\mathbf{3 e}$ & Casepase-3 & -291.6 & -291.6 & 0.0 \\
$\mathbf{3 f}$ & Casepase-3 & -210.3 & -210.3 & 0.0 \\
$\mathbf{3 g}$ & Casepase-3 & -216.7 & -194.5 & -22.2 \\
$\mathbf{3 h}$ & Casepase-3 & -229.7 & -229.7 & 0.0 \\
$\mathbf{3 i}$ & Casepase-3 & -179.2 & -179.2 & 0.0 \\
$\mathbf{3 j}$ & Casepase-3 & -229.0 & -229.0 & 0.0 \\
$\mathbf{3 k}$ & Casepase-3 & -260.6 & -260.6 & 0.0 \\
Standard & Casepase-3 & -320.3 & -320.3 & 0.0 \\
\hline
\end{tabular}

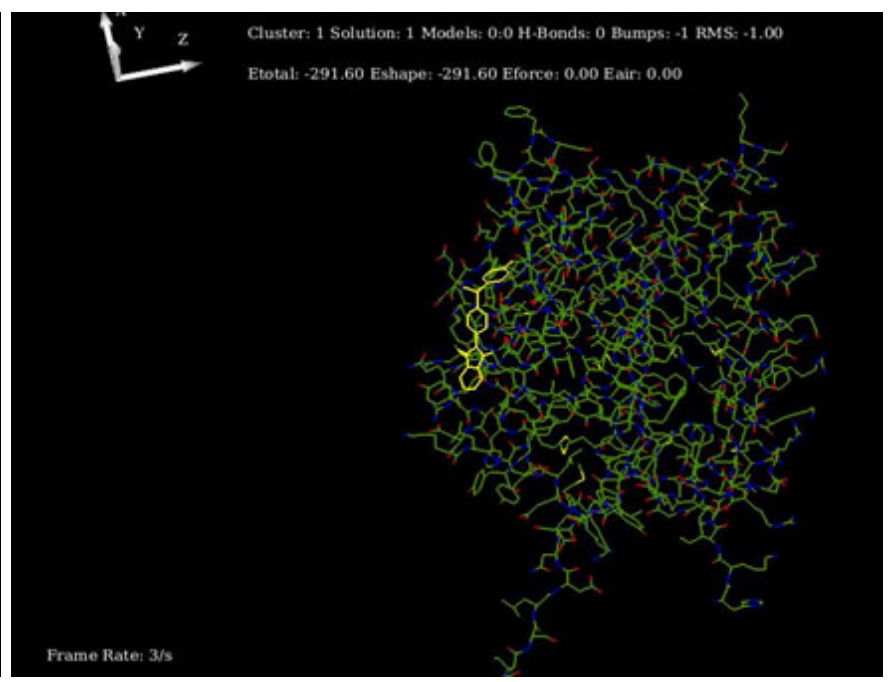

Fig. 2. Compound 3e interaction with caspase-3 receptor
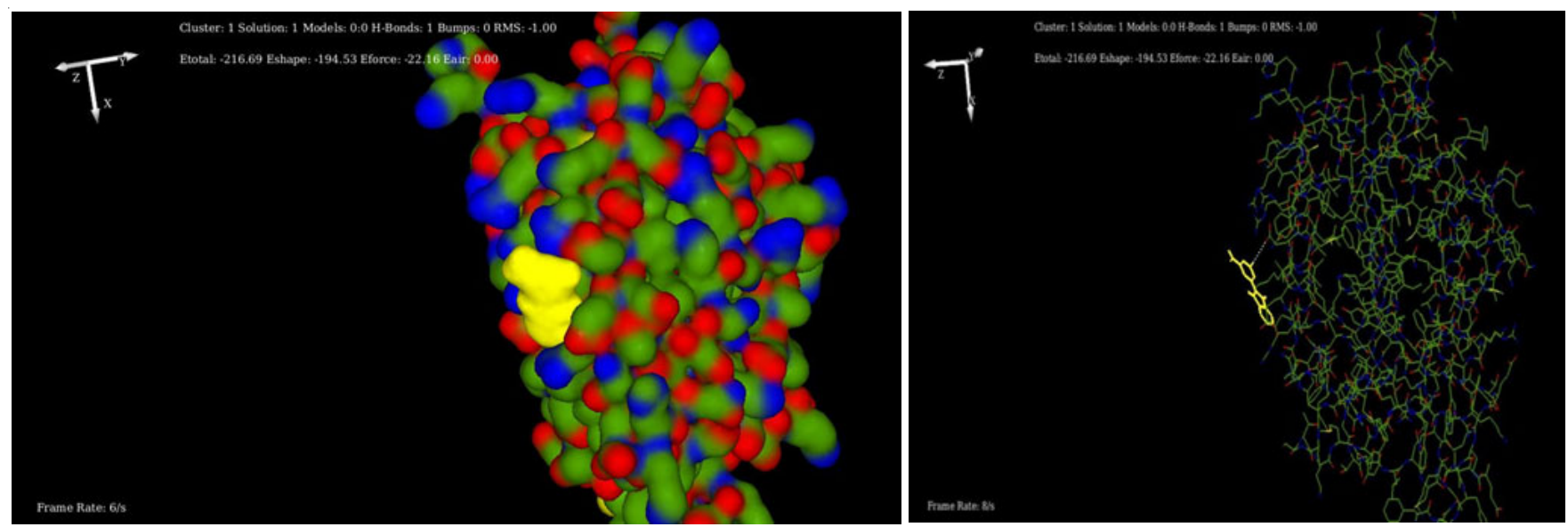

Fig. 3. Compound $\mathbf{3 g}$ interaction with caspase-3 receptor 
3e and $3 \mathbf{k}$ have the best binding energy of $-291.6 \mathrm{KJ} / \mathrm{mol}$ and $-260.0 \mathrm{KJ} / \mathrm{mol}$, respectively, which is close to the binding energy of standard [caspase inhibitor III $(-320.3 \mathrm{KJ} / \mathrm{mol})$ ]. The compound $\mathbf{3 g}$ showed hydrogen bond interactions to the active site of protein. This molecular docking gives accurate understanding for ligand and receptor binding interaction, which can be employed for developing new drugs against cancer.

in vitro Antioxidant activity: The antioxidant properties of these compounds were evaluated by two different in vitro methods namely, DPPH radical scavenging activity and ABTS radical scavenging activity. The DPPH and ABTS scavenging activities of all the synthesized compounds was screened at different concentrations by dissolving the compounds in methanol.

DPPH radical scavenging activity: The activity was assessed by measuring its electron donating ability to DPPH, which was indicated by changes in absorbance of the solution of different concentrations at $517 \mathrm{~nm}$. All the synthesized derivatives (3a-k) exhibited increased DPPH inhibitory percentage with the increase in concentration of standard antioxidants as shown in Fig. 4. It is understood that the lower the absorbance of the reaction mixture, the higher is the free radical scavenging activity. Among all the analyzed compounds, compound $\mathbf{3 e}$ have exhibited the highest inhibition (92\%) and the other compounds have shown inhibition in the range of 58-80 \% at a concentration of $5 \mathrm{mM}$ during the time duration of $90 \mathrm{~min}$. The $\mathrm{IC}_{50}$ values of compounds $\mathbf{3 a}-\mathbf{k}$ scavenging DPPH radical is presented in Table- 4 and the results show that the compound $\mathbf{3 e}$ has better DPPH radical activity $\left(\mathrm{IC}_{50} 1.74 \mathrm{mM}\right)$ than the other synthesized compounds. It can be seen from Table-4 that compounds $\mathbf{3 a}$, $\mathbf{3 c}$ and $\mathbf{3 h}$ also have better scavenging activity $\left(\mathrm{IC}_{50}\right)$ on DPPH radical. The compound $\mathbf{3 g}$ shows less scavenging activity $\left(\mathrm{IC}_{50}\right.$ $4.75 \mathrm{mM}$ ).

ABTS radical scavenging activity: The antioxidant property of the tested samples was evaluated at different concentrations. From Fig. 5, it was clear that all the isoindoline-1,3dione derivatives (3a-k) exhibited increased ABTS inhibitory percentage with the increase in concentration of standard antioxidants. Hence, it was assumed that they should be able to donate electrons to free radicals in the actual biological system. Among all the tested antioxidants, compound $\mathbf{3 e}$ has exhibited the highest inhibition of $96 \%$ and other compounds showed inhibition in the range of 58-82\% at a concentration of $5 \mathrm{mM}$ during the time duration of $90 \mathrm{~min}$. The $\mathrm{IC}_{50}$ values of compounds 3a-k scavenging ABTS radical is presented in Table-4 and

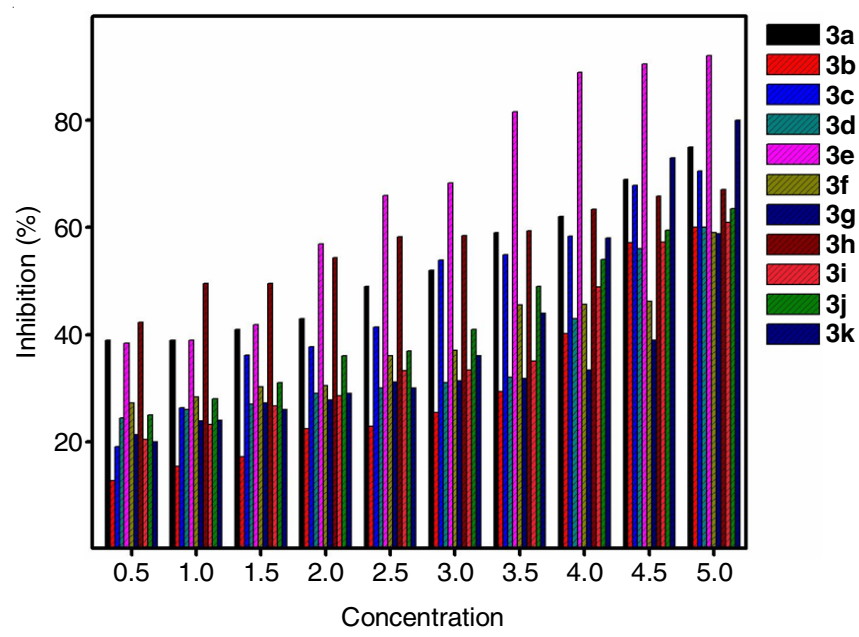

Fig. 4. DPPH inhibitory percentage of isoindoline-1,3-dione derivatives (3a-k) of different concentrations in $90 \mathrm{~min}$ after the addition of antioxidants to the DPPH radicals

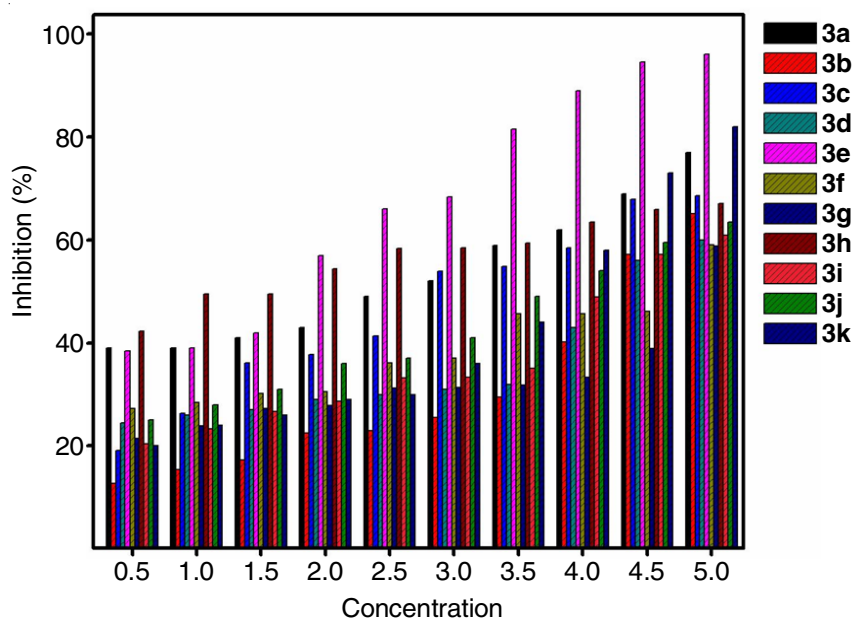

Fig. 5. ABTS inhibitory percentage of isoindoline-1,3-dione derivatives (3a-k) of different concentrations in $90 \mathrm{~min}$ after the addition of antioxidants to the ABTS radicals

the results showed that the compound $\mathbf{3 e}$ has better ABTS radical activity $\left(\mathrm{IC}_{50}: 1.69 \mathrm{mM}\right)$ than the other synthesized compounds. It can be seen from Table-4 that compounds 3a, $\mathbf{3 c}$ and $\mathbf{3 h}$ also have better scavenging activity $\left(\mathrm{IC}_{50}\right)$ on $\mathrm{ABTS}$ radical. The compound $3 \mathrm{~g}$ shows less scavenging activity $\left(\mathrm{IC}_{50}\right.$ : $4.68 \mathrm{mM}$ ).

TABLE-4

$\mathrm{IC}_{50}(\mathrm{~mm})$ VALUES OF EVALUATED DPPH AND ABTS ANTIOXIDANT ASSAY OF COMPOUNDS 3a-k

\begin{tabular}{|c|c|c|c|c|c|c|c|c|}
\hline \multirow{2}{*}{ Compound } & \multicolumn{4}{|c|}{ DPPH assay } & \multicolumn{4}{|c|}{ ABTS assay } \\
\hline & $30 \mathrm{~min}$ & $60 \mathrm{~min}$ & $90 \mathrm{~min}$ & Mean & $30 \mathrm{~min}$ & $60 \mathrm{~min}$ & $90 \mathrm{~min}$ & Mean \\
\hline $3 a$ & 4.59 & 2.78 & 2.65 & 3.34 & 4.53 & 2.75 & 2.63 & 3.30 \\
\hline $3 \mathbf{b}$ & 4.92 & 4.41 & 4.28 & 4.53 & 4.94 & 4.30 & 4.23 & 4.49 \\
\hline $3 c$ & 2.93 & 2.84 & 2.80 & 2.85 & 2.92 & 2.75 & 2.70 & 2.79 \\
\hline 3d & 4.91 & 4.69 & 4.28 & 4.62 & 4.94 & 4.70 & 4.30 & 4.64 \\
\hline $3 e$ & 1.96 & 1.80 & 1.74 & 1.83 & 2.00 & 1.78 & 1.69 & 1.82 \\
\hline $3 f$ & 5.00 & 4.80 & 4.63 & 4.81 & 5.00 & 4.76 & 4.66 & 4.80 \\
\hline $3 g$ & 4.89 & 4.78 & 4.75 & 4.80 & 4.86 & 4.70 & 4.68 & 4.74 \\
\hline $3 \mathrm{~h}$ & 3.64 & 2.99 & 1.85 & 2.82 & 3.60 & 2.95 & 1.80 & 2.78 \\
\hline $3 \mathbf{i}$ & 5.00 & 4.23 & 4.06 & 4.43 & 5.00 & 4.20 & 4.02 & 4.40 \\
\hline $3 \mathbf{j}$ & 4.81 & 4.00 & 3.62 & 4.14 & 4.76 & 3.98 & 3.63 & 4.12 \\
\hline $3 \mathbf{k}$ & 4.28 & 3.81 & 3.71 & 3.93 & 4.20 & 3.80 & 3.61 & 3.87 \\
\hline
\end{tabular}



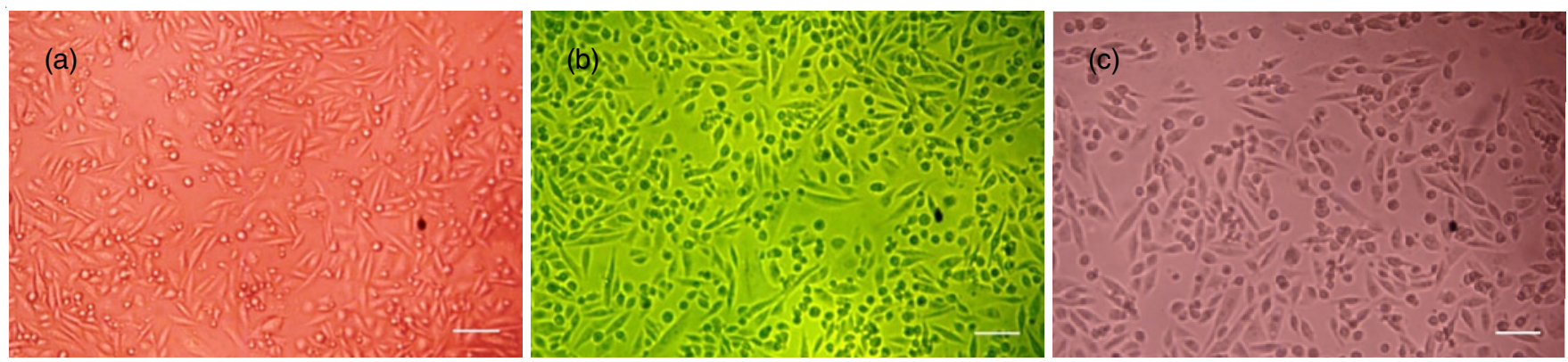

Fig. 6. (a) Cell inhibition for control on HeLa cell line, (b) Cell inhibition for standard drug on HeLa cell line, (c) Cell inhibition for compound 3e on HeLa cell line

in vitro Cytotoxicity activity: The compounds 3a-k was screened for in vitro cytotoxicity against human cervical cancer cell line (HeLa) using the MTT assay. Doxorubicin was used as the standard drug in this assay. All the analyzed compounds (3a-k) exhibited inhibition (cytotoxicity) activity on HeLa cells. At a concentration of $6 \mu \mathrm{g} / \mathrm{mL}$, no cytotoxic effect was observed when tested against the cells (cells survical were more than $90 \%$ ); but at a concentration of $85 \mu \mathrm{g} / \mathrm{mL}$, the compounds were effective on Hela cells. The compound $\mathbf{3 e}$ has exhibited the maximum inhibition (91\%) at a concentration of $85 \mu \mathrm{g} /$ $\mathrm{mL}$ and its viability was $09 \%$ as shown in Fig. 6c. Doxorubicin has exhibited an inhibition of $84 \%$ and viability of $16 \%$ at the same concentration of $85 \mu \mathrm{g} / \mathrm{mL}$. Compounds $\mathbf{3 a}, \mathbf{3 b}, \mathbf{3 d}$, $\mathbf{3 f}, \mathbf{3 g}, \mathbf{3 i}, \mathbf{3} \mathbf{j}$ and $\mathbf{3 k}$ displayed better inhibition percentage than the standard drug in the used concentration of $85 \mu \mathrm{g} / \mathrm{mL}$. The result of cytotoxic activity was expressed in terms of halfinhibition concentration $\left(\mathrm{IC}_{50}\right)$, which denotes the concentration required to inhibit $50 \%$ of Hela cells. The $\mathrm{IC}_{50}$ value of compound 3e shows better results ( $\mathrm{IC}_{50}: 20 \mu \mathrm{g} / \mathrm{mL}$ ) than the other compounds. Compounds $3 \mathbf{a}, \mathbf{3 b}, \mathbf{3 d}$ and $\mathbf{3 k}$ show better $\mathrm{IC}_{50}$ values than the standard drug doxorubicin as seen in Table- 5 .

\begin{tabular}{cc|cc}
\multicolumn{5}{c}{ TABLE-5 } \\
\multicolumn{4}{c}{$\begin{array}{c}\text { HALF-INHIBITION CONCENTRATION }\left(\mathrm{IC}_{50}\right) \\
\text { OF COMPOUNDS 3a-k ON Hela CELLS }\end{array}$} \\
\hline Compound & $\mathrm{IC}_{50}(\mu \mathrm{g} / \mathrm{mL})$ & Compound & $\mathrm{IC}_{50}(\mu \mathrm{g} / \mathrm{mL})$ \\
\hline 3a & 22.5 & $\mathbf{3 g}$ & 32.3 \\
3b & 23.2 & $\mathbf{3 h}$ & 42.0 \\
3c & 42.6 & $\mathbf{3 i}$ & 32.0 \\
3d & 22.4 & $\mathbf{3 j}$ & 40.3 \\
3e & 20.0 & $\mathbf{3 k}$ & 22.4 \\
3f & 36.8 & Doxorubicin & 26.4 \\
\hline
\end{tabular}

\section{Conclusion}

A series of isindoline-1,3-dione derivatives (3a-k) have been synthesized in the base free conditions with appreciable yields. The synthesized compounds were screened for their in vitro antioxidant activity employing the DPPH and ABTS methods. In this screening, compound $\mathbf{3 e}$ exhibited better inhibition efficiency in DPPH and ABTS methods. Among the studied compounds, $\mathbf{3 e}$ was the one with the best binding energy of $-291.6 \mathrm{Kcal} / \mathrm{mol}$ which is close to the binding energy of the standard. The entire set of compounds was also evaluated for their in vitro cytotoxicity against human cervical cancer cell line (HeLa). All the synthesized compounds exhibited inhibition (cytotoxicity) against HeLa cells and compound $\mathbf{3 e}$ exhibited the maximum inhibition and its viability was $9 \%$. Compounds $\mathbf{3 a}, \mathbf{3 b}, \mathbf{3 d}$ and $\mathbf{3 k}$ show better $\mathrm{IC}_{50}$ values than the standard drug doxorubicin. Some drugs are available for treating cancer cells, there is still a need for safe and effective drugs. Therefore, the synthesized fluorescein derivatives and phenolphthalein derivatives might turn out to be a potential lead for the development of drug molecules having cytotoxicity activity.

\section{CONFLICT OF INTEREST}

The authors declare that there is no conflict of interests regarding the publication of this article.

\section{REFERENCES}

1. L. Wyld, R.A. Audisio and G.J. Poston, Nat. Rev. Clin. Oncol., 12, 115 (2015);

https://doi.org/10.1038/nrclinonc.2014.191.

2. R. Baskar, K.A. Lee, R. Yeo and K. Yeoh, Int. J. Med. Sci., 9, 193 (2012); https://doi.org/10.7150/ijms.3635.

3. A. Urruticoechea, R. Alemany, J. Balart, A. Villanueva, F. Vinals and G. Capella, Curr. Pharm. Des., 16, 3 (2010); https://doi.org/10.2174/138161210789941847.

4. A. Alam, U. Farooq, R. Singh, V.P. Dubey, S. Kumar, R. Kumari, K.K. Naik, B.D. Tripathi and K.L. Dhar, Open Acc. J. Toxicol., 2, 1 (2018); https://doi.org/10.19080/OAJT.2018.02.555600.

5. G.H. Elgemeie, A.B. Farag, K.M. Amin, O.M. El-Badry and G.S. Hassan, Med. Chem., 4, 814 (2014); https://doi.org/10.4172/2161-0444.1000234.

6. K.N. Mohana and C.B.P. Kumar, ISRN Org. Chem., 2013, 1 (2013); https://doi.org/10.1155/2013/620718.

7. S.R. Archie, B.K. Das, M.S. Hossain, U. Kumar and A.S.S. Rouf, Int. J. Pharm. Pharm. Sci., 9, 308 (2016); https://doi.org/10.22159/ijpps.2017v9i1.14972

8. M. Van Bulck, A. Sierra-Magro, J. Alarcon-Gil, A. Perez-Castillo and J.A. Morales-Garcia, Int. J. Mol. Sci., 20, 719 (2019); https://doi.org/10.3390/ijms20030719.

9. P. Singh, R. Kumar, S. Tiwari, R.S. Khanna, A.K. Tewari and H.D. Khanna, Clin. Med. Biochem., 1, 105 (2015); https://doi.org/10.4172/2471-2663.1000105.

10. A.M. Dar and S. Mir, J. Anal. Bioanal. Technol., 8, 8 (2017); https://doi.org/10.4172/2155-9872.1000356.

11. R.M. Jagtap and S.K. Pardeshi, Der Pharm. Lett., 6, 137 (2014).

12. M. Kumar, K. Sharma, R.M. Samarth and A. Kumar, Eur. J. Med. Chem., 45, 4467 (2010); https://doi.org/10.1016/j.ejmech.2010.07.006.

13. N. Sener, S. Eriskin, S. Yavuz and I. Sener, J. Heterocycl. Chem., 54, 3538 (2017); https://doi.org/10.1002/jhet.2977.

14. K.F. Hamak, Int. J. ChemTech Res., 6, 324 (2014).

15. A. Kamal, N.R. Bolla, P.S. Srikanth and A.K. Srivastava, Expert Opin. Ther. Pat., 23, 299 (2013); https://doi.org/10.1517/13543776.2013.746313. 
16. K.M. Amin, A.H. El-Masry, N.A. Mohamed, G.E.A. Awad and B.S. Habib, Der Pharm. Chem., 5, 97 (2013).

17. S. Rajasekaran, G.K. Rao and A. Ranjan, Int. J. ChemTech Res., 3, 555 (2011).

18. A.L. Machado, L.M. Lima, J.X. Araujo-Jr, C.A.M. Fraga, V.L. Gonçalves Koatz and E.J. Barreiro, Bioorg. Med. Chem. Lett., 15, 1169 (2005); https://doi.org/10.1016/j.bmcl.2004.12.012.

19. C.S.C. Kumar, W.S. Loh, S. Chandraju, Y.-F. Win, W.K. Tan, C.K. Quah and H.-K. Fun, PLoS One, 10, e0119440 (2015); https://doi.org/10.1371/journal.pone.0119440.

20. M.R. Shiradkar, M. Ghodake, K.G. Bothara, S.V. Bhandari, A. Nikalje, K.C. Akula, N.C. Desai and P.J. Burange, ARKIVOC, 58 (2007); https://doi.org/10.3998/ark.5550190.0008.e08.

21. V.K. Pandey, S. Tusi, Z. Tusi, R. Raghubir, M. Dixit, M.N. Joshi and S.K. Bajpai, Indian. J. Chem., 43B, 180 (2004).

22. W. Zhou, S. Li, W. Lu, J. Yuan, Y. Xu, H. Li, J. Huang and Z. Zhao, MedChem Comm, 7, 292 (2016); https://doi.org/10.1039/C5MD00469A.

23. P.M.P. Ferreira, P.M.D. Costa, A.D.M. Costa, D.J.B. Lima, R.R. Drumond, J.D.N. Silva, D.R.D.M. Moreira, G.B.D. Oliveira Filho, J.M. Ferreira, M.G.R.D. Queiroz, A.C.L. Leite and C. Pessoa, An. Acad. Bras. Cienc., 87, 313 (2015); https://doi.org/10.1590/0001-3765201520130345.

24. A. Aliabadi, A. Foroumadi, M. Safavi and S.K. Ardestani, J. Rep. Pharm. Sci., 1, 23 (2012).

25. A.K. Singh, J.K. Bhardwaj, A. Olival, Y. Kumar, A. Podder, A. Maheshwari, R. Agrawal, N. Latha, B.K. Singh, H. Tomás, J. Rodrigues, R. Kishan, B. Rupini and B. Rathi, J. Chem. Sci., 128, 1245 (2016); https://doi.org/10.1007/s12039-016-1122-0.
26. N. Singh, I.M. Khan, A. Ahmad and S. Javed, New J. Chem., 41, 6810 (2017); https://doi.org/10.1039/C7NJ00819H.

27. M. Shakir, N. Bano, M.A. Rauf and M. Owais, J. Chem. Sci., 129, 1905 (2017); https://doi.org/10.1007/s12039-017-1398-8.

28. R.K. Sahu, M. Kar and R. Routray, J. Med. Plants Stud. (Roma), 1, 21 (2013).

29. J.B. Veselinovic, A.M. Veselinovic, Z.J. Vitnik, V.D. Vitnik and G.M. Nikoliæ, Chem. Biol. Interact., 214, 49 (2014); https://doi.org/10.1016/i.cbi.2014.02.010.

30. G. Mencia, N.S. del Olmo, L. Munoz-Moreno, M. Maroto-Diaz, R. Gomez, P. Ortega, M. José Carmena and F. Javier de la Mata, New J. Chem., 40, 10488 (2016); https://doi.org/10.1039/C6NJ02545E.

31. K. Adach, M. Fijalkowski, G. Gajek, J. Skolimowski, R. Kontek and A. Blaszczyk, Chem. Biol. Interact., 254, 156 (2016); https://doi.org/10.1016/j.cbi.2016.06.004.

32. A. Adamski, M.A. Fik, M. Kubicki, Z. Hnatejko, D. Gurda, A. FedorukWyszomirska, E. Wyszko, D. Kruszka, Z. Dutkiewicz and V. Patroniak, New J. Chem., 40, 7943 (2016); https://doi.org/10.1039/C5NJ03601A

33. D. Gerlier and N. Thomasset, J. Immunol. Methods, 94, 57 (1986) https://doi.org/10.1016/0022-1759(86)90215-2.

34. S.J. Kumar, S. Shaji and V.M.B. Grace, Asian J. Pharm., 10, 183 (2016).

35. A.G. Porter and R.U. Janicke, Cell Death Differ., 6, 99 (1999); https://doi.org/10.1038/sj.cdd.4400476. 